Why Do Political Philosophers Disagree? Reflections on David Miller's Strangers in Our Midst

\author{
Joseph H. Carens \\ University of Toronto
}

Prepared for presentation at the Berkeley Workshop in Law, Philosophy, and Political Theory on September 8, 2017. Rough draft lacking proper citations. Numbers in parentheses refer to pages from David Miller, Strangers in Our Midst: The Political Philosophy of Immigration (Cambridge: Harvard University Press, 2016). References to my book are to Joseph H. Carens, The Ethics of Immigration (New York: Oxford University Press, 2013). 
CARENS Why Do Political Philosophers Disagree?

I hope that I do not have to add an emoticon to my title to signal that the question I ask there is intended to provoke a smile (as are some of my other comments below, but I leave it to the reader to determine which ones). A cynic (or perhaps a neoliberal) might respond to the title question by saying, "Political philosophers disagree because that is what they are paid to do." And that is not just a cynical (or neoliberal) response. A great deal of our training as political philosophers involves encouragement in distinguishing our own ideas from those of others and in criticizing theirs. There are few professional rewards for saying, "I agree with $\mathrm{x}$ " (unless $\mathrm{x}$ is famous and you go on to say why y and $\mathrm{z}$ are wrong). Still, there is (or ought to be) a puzzle here because philosophers, including political philosophers, are supposed to be seekers of the truth, and in a quest for the truth one might expect, or at least hope, that there would be many areas of agreement among political philosophers and that it would be as important to draw attention to those areas of agreement as it is to the areas of disagreement. In addition, one might hope that philosophers would be interested in understanding why their fellow philosophers disagreed with them instead of contenting themselves with proving their fellow philosophers wrong.

That is precisely the path I propose to follow in this paper. When Sarah and Josh invited me to present a paper to the workshop, I told them that I'd like to use the occasion to engage with David Miller's recent book. As I'm sure you all know, David Miller is one of the world's leading political theorists writing in the Anglo-American tradition. He and I have been exchanging ideas about immigration for many years both in print and in person. I like David Miller personally, and I have great admiration and respect for him as a scholar. And yet we appear to disagree. I suspect that many people who follow the immigration debate - note the term - from a distance, and perhaps even some who follow it from close up, think of us as fundamentally at odds in our views: Carens is a cosmopolitan idealist who favours open borders, they may say, and Miller is a liberal nationalist realist who defends the state's right to control admissions. That's not an entirely incorrect snapshot, but it is also a misleading and incomplete picture in many important respects. So, I want to use this occasion to give a fuller view of the landscape, identifying the areas of agreement between Miller and me (and they are many). Moreover, when it comes to the areas where our views differ (and they exist as well), I'd like to do a bit more than engage in the usual philosophical exercise of explaining why I am right and Miller is wrong. I won't entirely forego that pleasure - after all, I have been trained as a political philosopher - but I want to focus more upon the question of whether we really disagree and in those cases where we do disagree (which will be fewer than most think) I'd like to try to probe a bit more into the question of why we do. My hope is that this exercise may encourage others to move (at least occasionally) beyond arguments with their fellow theorists to reflect upon the nature of those arguments in the hope that such reflection may reduce the amount of noise in academic discussions and increase the amount of light.

One difference between Miller and me, though I don't think it counts as a disagreement, is the order in which we take up the issues that both of us discuss. I have no objection to Miller's order. There are always advantages and disadvantages to the order in which one takes up topics and often no compelling reason to choose one order over another. I don't think that either order has much impact on our substantive discussion of particular issues. In this paper, I'll follow an order that does not coincide precisely with the one in either of our books. My plan is to start with the 
CARENS Why Do Political Philosophers Disagree?

topics on which we seem to agree the most and move more or less along the course of increasing differences. The philosophical impulse to focus on disagreement, or at least apparent disagreement, is hard to resist even when one is consciously trying to do so. Nevertheless, I will remain true to my commitment to focusing on agreement by not spending much time on the substantive issues where I think our disagreement is in fact the greatest, i.e., on the open borders debate. I will limit myself to some comments on the topics that Miller uses to frame that debate, namely the choice of a realistic or an idealistic approach and the relationship between partiality and cosmopolitanism. The order in which I will discuss topics is this: the selection of immigrants, the rights of temporary workers, the rights of permanent residents, the treatment of irregular migrants, the integration of immigrants, access to citizenship, refugees, realism and idealism, and finally partiality and cosmopolitanism.

Let's start with a brief overview of some of Miller's key claims. Early on in his book, Miller says,

For societies that aspire to live up to liberal-democratic principles, it is intolerable for there to be a class of persons consigned permanently to hold a subordinate status within their borders. So all the immigrants who are destined to remain must be given the opportunity to gain rights of residence and eventually full rights of citizenship... (7)

In the concluding chapter, he provides a related summary of his basic position:

Both admission policies and integration policies should aim at ensuring that immigrants become full members of the societies they join, regarded and treated as equal citizens by the indigenous majority, identifying with the society, and participating widely in its social and political life. This does not mean "assimilation." Immigrants are also entitled to retain their specific group-based identities and their cultural differences. But because their rights and opportunities should be exactly the same as those of the native born, it would be a worrying sign if immigrants turned out to achieve markedly different levels of success in spheres such as education, the economy, and politics. (161)

I agree fully with both of these general statements. Of course, agreement on general principles can sometimes mask important disagreements about details. So, let's turn to the specifics.

\section{Selecting immigrants}

When it comes to questions about the criteria that a liberal democratic state may use in selecting immigrants for admission, Miller and I seem to be basically in agreement, although each of us discusses some topics that the other does not address. We both agree, however, that if we start from the view that states are morally entitled to exercise considerable discretionary control over immigration (a view that Miller defends and that I adopt as a presupposition for purposes of analysis), a liberal democratic state may give preference to the admission of immigrants it thinks will contribute economically but may not use factors like race, ethnicity, religion, sexuality, and gender in deciding whom to admit. (102-105) Like Miller, I think that it is acceptable for a state 
CARENS Why Do Political Philosophers Disagree?

(and, in some cases, a political community within a state) to give positive weight to knowledge of the language of public life in decisions about admissions. Miller seems to think it is also acceptable (though not always advantageous) for a state to give weight to other cultural characteristics as well, though, so far as I can tell, he does not offer many specifics about the sorts of cultural criteria besides linguistic knowledge that could be used in selection without counting as morally objectionable discrimination. He is explicitly quite wary of using political beliefs as a screen, at least under normal circumstances, and I agree. (105-106)

\section{The rights of temporary workers}

Under the same background assumptions as above about the state's right to exercise discretionary control over admissions, Miller and I agree that it is morally permissible for states to admit immigrants as temporary workers. We also agree that temporary workers cannot claim as a matter of justice all of the rights of citizens or permanent residents (e.g., access to redistributive social programs), but that they are morally entitled to a wide range of legal rights. So, they are entitled not only to protection of their basic human rights but also to civic freedoms and to whatever legal protections the state has established with regard to health and safety at work, minimum wages, and so on. He thinks, as I do, that it is not fair to expect temporary workers to contribute to insurance schemes (e.g., pension plans) if they are not entitled to benefit from those arrangements. (99) The other key point of agreement is that it is not morally permissible for democratic states to keep people in a temporary status for an extended period. Miller is actually a bit more demanding in this regard than I was. He says the maximum should be a year or two whereas I pointed to the EU policy of setting a maximum limit of five years for temporary status, but I'd be happy to accept his stricter limits.

\section{The rights of residents}

Miller does not discuss specifically what legal rights permanent residents should have before they become citizens (and apart from access to citizenship which I discuss separately below) but we can infer from what he says in the general statements cited above and from the way he discusses the social, civic, and cultural integration of immigrants that he thinks, as I do, that permanent residents should normally enjoy the same legal rights as citizens apart from political rights and responsibilities. In my book, I note three other areas where states sometimes still differentiate between citizens and residents but where I think they normally should not (with some minor qualifications): security of residence, access to public employment, access to redistributive social programs. The underlying justification that I offer in support of this position is that residents should be regarded as full members of society and that is a position that Miller also clearly embraces. I don't know whether he would agree with the specifics of my views on these topics, however, because there are some competing considerations, and it is possible that he would weigh the values at stake somewhat differently. If there are differences, however, they do not appear to be big ones.

\section{Irregular migrants}

What about immigrants who settle without state authorization? In my book I call these people irregular migrants. I argue that they are morally entitled to receive legal protection of their basic 
CARENS Why Do Political Philosophers Disagree?

human rights, that their children are morally entitled to a free public education, that the migrants themselves cannot claim a legal right to work but should have a legal right to their contractually agreed upon pay if they do work, and that the state has an obligation to see that its rules regarding health and safety standards at work are respected even when the workers are irregular migrants. I also argue that the state is obliged to create a firewall between the enforcement of immigration restrictions on the one hand and its protection of the basic human rights of irregular migrants, its provision of education for their children, its protection of their claims to be paid for work performed, and its enforcement of health and safety standards on the other. I do not claim that irregular migrants are morally entitled to all of the social and other economic rights enjoyed by immigrants, even temporary ones, admitted with state authorization. Finally, I argue that over time irregular migrants become members of society and so are morally entitled to have their status regularized with access to legal permanent residence status and eventually access to citizenship on the same terms as other residents.

What does Miller think about this issue? I might describe his position as one of grudging acquiescence. As I read him, he does not want to embrace my position, but for the most part he does not see a better alternative. He does not like the term irregular migrants but he uses it. (199, n.1) He does clearly think that irregular migrants are morally entitled to protection of their basic human rights, but he expresses some skepticism about the firewall argument, both in terms of principle and in terms of its feasibility. Ultimately, however, he seems to think that a firewall is warranted when it comes to basic human rights. (117-119) He does not say whether he thinks a firewall is also appropriate when it comes to providing education for the children of irregular migrants, to ensuring that irregular migrants are paid for work performed, or to enforcing health and safety standards. He does say that a firewall "should only apply to interactions between immigrants and public institutions where basic rights are at stake," which might seem to preclude a firewall in at least some of these cases. (120) In any event, I think his restriction is too strong, in part because it does not acknowledge that there can be public policy reasons for creating this sort of firewall in other areas. For example, people sometimes argue that irregular migrants should be able to obtain drivers licenses and car insurance without risking their immigration status because this reduces risks to the rest of the population. Whether the claim about the effects of such a policy are accurate or not, it is an argument for a firewall based on the broad consequences of the policy, not on claims about the moral rights of irregular migrants. But is this really a disagreement with Miller or simply an objection to a particular formulation of his? I suspect the latter, and so while it's worthwhile clarifying the issue, I doubt that it is really a substantial difference.

With respect to the regularization of the legal status of these migrants, Miller is again ambivalent because of the challenges that regularization poses to democratic control of admissions, though he ultimately gives the most weight to inclusion. He suggests that the best approach, partly for reasons of principle and partly for policy reasons, is "conditional amnesty," though how far that differs from my view that length of residence alone should suffice depends on how stringent the other conditions are and what sort of discretion there is to deny regularization. After all, requiring irregular migrants to have been living in the society for a period of time before becoming eligible for amnesty in itself makes regularization conditional. If the conditionality of 
CARENS Why Do Political Philosophers Disagree?

amnesty merely required that the irregular migrant not only have been present for a specified length of time but also have been employed or engaged in some valuable social activity like raising children during some significant part of that period, the difference between us would not be very great. The greater the demands, the greater the difference would be. Miller is not very specific about this, but the thrust of his argument is clearly towards the regularization of most long-term irregular migrants, and his justification is that they have indeed become members of society over time despite their settling without authorization. So, in the end, our views on this again seem pretty close.

\section{The social, civic, and cultural integration of immigrants}

This is another topic on which I do not see any clear difference between Miller and me at the level of principle except for certain questions relating to civic integration which I defer to the next section. I use his terms for the heading here for topics that I discuss under the heading of "inclusion," but I have no objection to the term integration in the way Miller uses it (and have used the term myself that way in the past). Miller's statement from the concluding chapter of his book that I quoted earlier nicely captures the key points on this topic, and, as I said before, I agree fully with it. We both emphasize the importance of nondiscrimination as a key to successful integration. We both agree that liberal freedoms imply that immigrants are entitled to maintain many distinctive cultural features regarding dress, diet, religious practices, and so on. At the same time, we both talk about the need for immigrants to adapt to the public institutions and culture of the receiving society in many ways. We both see therefore a need for mutual adjustments between the current citizenry and immigrants in social life, and we agree that while immigrants can reasonably be expected or even required to adapt to established institutions and practices in many ways, they also have a right to expect the established order to change rules and practices or to find other ways to accommodate their religious and cultural commitments.

There are differences of nuance and emphasis. Miller stresses the importance of social integration and the dangers of social segregation, while I think there are good reasons for immigrants to want to cluster together at first, and the more important question is how this plays out over the longer run, especially with the second generation. Perhaps this simply reflects differences between the Canadian and British (or North American and European) experiences or differences in our reading of the empirical literature. In any event, we both favour policies that promote social equality while respecting individual freedom, and I agree with Miller that it will be difficult to achieve social equality in the long run without social integration.

There is one sort of difference between Miller and me, however, that seems much deeper than this difference over social integration, and that has to do with the different judgments we make about what I will call the morally legitimate space for recognition of the majority's culture and its association with national identity. Miller and I agree that the public culture is not neutral and will inevitably reflect the culture of the majority to a greater extent than the culture of immigrants. We also agree, I think, that the national identity must be inclusive, i.e., that it must be understood in a way that can readily include immigrants even though it will have historically and culturally specific features. So, there are many concrete practices and examples on which we would agree. But sometimes when he and I consider specific cases of what are and are not 
CARENS Why Do Political Philosophers Disagree?

acceptable ways of respecting historical and cultural specificity in public life or in the state's national identity, we seem to inhabit different spheres.

Let me mention two examples that stand out for me. In my book, I mention the fact that the Swiss had a referendum and passed a constitutional amendment banning the building of any new minarets, and I describe this as an obvious and deeply objectionable example of the negative recognition of immigrants' cultural and religious identity. I say, "It would be hard to imagine a more direct way of communicating the message that Muslim citizens of immigrant origin are not welcome or that Islam is not part of the Swiss national identity." (Carens, 83) Miller mentions this specific issue only in passing in his book (148, see n. 42), but he has written a scholarly article on it and on the wider issues raised by this case. In the article, he does not defend the Swiss decision, but his criticism of it rests primarily on details as to how it was reached, and he does defend in principle the possibility of limiting the public visibility of minority religions (so long as people are free to worship and practice their religion) in order to preserve the traditional association of public space with the majority's religion. So, there is a stark contrast between my assessment of this case and Miller's despite our shared general principles regarding integration.

The second, related example is not quite as dramatic, but the difference remains very strong. In his book Miller explicitly defends the continued practice of having crucifixes in public school classrooms in Italy on the grounds that they only "reflect the country's Catholic heritage." (146) He suggests that objecting to this Italian practice could equally justify objecting to the French subsidizing its film industry or the UK distributing works of Shakespeare. (146) I find this line of argument perplexing. I would have no trouble seeing financial support for the French film industry as compatible with respect for immigrants (so long as immigrant film makers were eligible for the subsidies as well). Similarly, I would have no trouble in seeing Shakespeare as part of the required curriculum in any English language educational system and so something immigrant children could also be required to read (though I would be quite concerned if the contemporary literature in the curriculum contained no immigrant authors, given their actual abundance). Finally, I would not say that Italy has to repudiate or conceal its Catholic heritage. Indeed I think there are ways in which Italy could take steps to protect that heritage to which I would have no objection (e.g., by spending public funds to preserve and display Italian Christian art in museums or even to maintain the physical upkeep of historically important religious buildings like cathedrals). But in my view a crucifix in a classroom is not remotely in the same category as these other forms of recognition of, and support for, Italy's Catholic heritage. Mandating a crucifix in the classroom does not entail an explicit message of exclusion in the way that banning minarets does, especially if, as I think is the case here, the practice long predates the presence of (many) non-Catholics in the school system and is not a reaction to the increasing number of non-Catholics who are members of the society. Nevertheless, the crucifix is a powerful religious symbol, and to require its presence in a classroom of young children even when some of them do not share that religion and may be troubled by its presence is problematic. If it is presented as an expression of national identity, then I think it implies an understanding of national identity that is not sufficiently inclusive. 
CARENS Why Do Political Philosophers Disagree?

I am genuinely puzzled as to why Miller's and my views of these cases are so far apart, given our agreement at the level of principle when we write about national identity, cultural integration, and so on. What lies behind or gives rise to these very different judgments? Do we have different views of some facts, and, if so, what are those facts and what would count as evidence for or against either view? Do we weigh competing values differently, and, if so, what are those competing values? Or are these crude categories (facts and values) the wrong frames for thinking about this puzzle? My guess, and frankly it is only a guess at this point, is that the difference in judgments may reflect a difference in sensibilities. I think that I am particularly attuned to what I see as the dangers of exclusion and Miller is particularly attuned to what he sees as the dangers of homogenization or thinning of distinct national identities. Perhaps this difference in sensibilities gives rise to our different assessments of these cases. But I am open to other suggestions.

\section{Access to citizenship}

Now consider access to citizenship. I spend some time in my book explaining why the children of permanent residents should get citizenship at birth and why any children raised in a society for an extended period should gain citizenship unconditionally and automatically upon reaching a certain age. As far as I can tell, Miller does not discuss either of these issues explicitly, but he does emphasize how important the educational process is in inculcating appropriate values and attitudes in citizen children. In another context in which he emphasizes the potential moral relevance of the fact that immigrants have chosen voluntarily to enter a society rather than being involuntarily being born into it like non-immigrant citizens, he comments in a footnote, "I am distinguishing between chosen and unchosen membership, and 'native-born' should therefore be read to include children raised in a society regardless of their precise place of birth." (201, n. 25). This suggests to me that Miller is assuming that all of the 'native-born' should be granted citizenship automatically and unconditionally, which is basically the view I defend. It is worth noting, however, that not all states grant citizenship automatically to the children of immigrants born in the state to which their parents have moved, and even those that do normally fail to extend citizenship automatically to children who arrive at a very young age and are raised in the society. So, if Miller does agree with me about access to citizenship for the children of immigrants, both of us are criticizing one common aspect of the rules governing access to citizenship in most democratic states today.

On the issue of naturalization for immigrants who arrive as adults, there is a difference between Miller and me. In practice, the difference is not a big one, but there is a larger theoretical disagreement behind it, and that contrast may also illuminate a difference between Miller and me about the nature and purposes of political theory. As the initial quotation above from page 7 of Miller's book indicates, he thinks that all immigrants permanently residing in a society should be put on a path to citizenship, an idea that he repeats in other places in his book. As I said, I agree with this. Miller also thinks that it is important for democratic states to foster the civic integration of immigrants which depends upon their learning the language of public life, at least to some extent, and learning about the civic values, the political institutions, and even the history 
CARENS Why Do Political Philosophers Disagree?

of the society to which they have moved. Again, I agree that this sort of civic integration is important and desirable. (Carens, 66)

The difference between us lies only (or at least primarily) in what we think of citizenship tests. Miller thinks that a reasonable way to foster civic integration is to require immigrants to pass a test in order to gain citizenship, so long as the test is not too demanding. Such tests, he says, are valuable because (1) they "ensure that the person taking the test has learnt the national language ... sufficiently well to be able to complete it," (2) "they help to emphasize that becoming a citizen is a serious matter," and (3) if the tests contain questions about democracy, the applicant "will at least know what the society expects of her politically." (128) ${ }^{1}$

Miller acknowledges that having a test can mean that some may fail, even after repeated attempts, and thus will remain only permanent residents. He characterizes the position of such people as "anomalous and unenviable," but he sees that as a cost worth paying to get immigrants to regard the acquisition of citizenship as "an important accomplishment." (138) "What matters," he says, "is that the test should be passable by anyone who puts in a modest amount of effort in

\footnotetext{
${ }^{1}$ In another passage Miller criticizes me for objecting to citizenship tests "on the grounds that they do not track the requirements for being a competent citizen.” (138) He then says,

the objection misunderstands the purpose of citizenship tests. ...they serve two purposes. One is to provide an incentive to those preparing for the test to learn something about the political system that governs them... The other is to serve as an implicit statement of the nation's political values at any moment. (138)
}

I confess that I find myself baffled by Miller's critique. The purposes that he introduces here seem different from with the ones he has described earlier (and, I would add, more problematic). As the passage that I have quoted in the text makes clear, Miller previously described the tests as a way to ensure that applicants have a certain level of linguistic ability which he himself then characterized as "an important precondition for political participation." (128) That certainly sounds as though the test is intended to assess one sort of civic competence. And he followed the sentence quoted above about the test teaching applicants about "what the society expects of her politically" by saying, "She is being told that if she is going to be politically active, there are certain ground rules she will have to observe." (128) Again, that sounds as though the test is intended to assess another sort of civic competence: knowledge of what is expected of those who engage in democratic politics. And if one had any doubt about my interpretation of Miller's language as implying that citizenship tests are tests of civic competence in my sense of the term, there is Miller's own statement on the following page: “...if one starts from the assumption [as Miller himself does] that access to citizenship should be within the reach of all subject only to showing a modicum of political competence, then a waiting period plus success in a formal test... should be a sufficient qualification." (129) In this passage the idea that the purpose of a citizenship test is to assess civic competence (i.e., to determine whether or not someone has "a modicum of political competence") is made explicit and unambiguous. And once one recognizes that as the purpose of the test, it seems reasonable to ask whether a formal test is the best way to determine whether an adult immigrant does indeed have "a modicum of political competence." I was suggesting that it is not because the sorts of things that a formal test can measure (linguistic ability and knowledge of the rules) are not really the most reliable indicators of civic competence properly understood, even at a minimum or "modicum" level. I have relegated this comment to a footnote because it is really just an objection to what I see as a minor inconsistency in Miller's presentation, and one that I mention at all only because he was criticizing me. It did occur to me that, in principle, I should not care about the fact that I was the object of the critique, but as I note at various points, there is often a gap between principle and practice. 
CARENS Why Do Political Philosophers Disagree?

preparing for it, and that there is support for those who, for example, have reading or comprehension difficulties." (139) Miller says explicitly that he does not think it is appropriate for officials to have any discretion in granting citizenship once someone has met the residence requirement and passed the formal test.

In one way, I agree with Miller about much of this. When I discussed the issue of access to citizenship for adult immigrants in my book, I first said this:

The crucial claim that I am making in this chapter is that citizenship should be easily accessible as a matter of right to immigrants who want it after they have been in the country for a few years. That is largely compatible with tests of linguistic and civic knowledge, if the requirements for passing the tests are set at appropriately modest levels so that most immigrants can pass the tests without difficulty. (Carens, p. 55)

As you can see, that sounds quite compatible with Miller, and I have said previously that I endorse the idea of promoting civic integration, including finding ways to encourage immigrants to learn the language of public life and to learn about the political institutions and practices of the society they have joined. So where are the differences between Miller and me?

One difference may be in the way in which we interpret the idea that the tests should not be too demanding. I asserted in my book that some states, such as the Netherlands, are using tests that are far too difficult. Miller does not say whether he regards any current citizenship tests as too demanding, but he mentions three (the UK, Canada, and the US) that he thinks are acceptable in what they expect. He notes that $75 \%$ of those who take the British test pass and says that he doubts that many UK-born citizens could pass the test without preparing specifically for it, but he says that he thinks the requirements of the test are reasonable. I was myself a bit taken aback at the idea that a reasonable test is one that is failed by $25 \%$ of those taking it and that ordinary native citizens could not pass without special preparation. Those details left me wondering whether the test is really requiring only a "modicum" of political competence. And this draws attention again to the fact that an agreement on abstract formulations can sometimes conceal real differences if one does not specify the concrete implications of those formulations. That should be a cautionary note in any theoretical exploration. On the other hand, without further discussion of specifics, I don't know how far apart Miller and I would be, if at all, on what we would regard as morally permissible citizenship tests.

I think that there is a deeper difference between us, however, which partly involves what we think about citizenship tests and partly involves what we think is the goal of a political theory of immigration. I argue in my book that, if we focus only on what democratic principles require and not on what makes sense as a policy today, then we will see that citizenship tests are an illegitimate means to the legitimate goal of civic integration. Citizenship tests are unjust in principle, no matter how easy it is to pass them, because they make access to citizenship contingent for people who have a moral right to citizenship because of their life circumstances (i.e., in this case, sufficiently long residence in the society). I argue that the use of citizenship tests in this way reflects a conception of citizenship that was common in the past but is no longer 
CARENS Why Do Political Philosophers Disagree?

seen as morally defensible. I will not repeat the details of my argument here (so as to encourage you to buy my book -- or at least to read pp. 56-60 online). The point to which I want to draw attention is that after arguing that citizenship tests are unjust in principle, I also argue that we should probably not try to change public policies and abolish such tests altogether. Instead, we should accept them so long as the demands of the test are modest. Again, I will not repeat here the contextual and prudential reasons I give for this approach to naturalization as an issue of public policy. What I want to draw attention to instead is a difference between Miller and me that is revealed by this line of argument in my book.

Does Miller really disagree with me that citizenship tests conflict with the principle that, to use his own words, "all permanent residents are entitled to become citizens after a suitable period of time has elapsed"? (137) He says, "Whether there is indeed a contradiction here depends on how easy or difficult it is to ...pass the test." (137) But logically, it seems as though it makes more sense to say that what depends on the relative difficulty of the test is not whether there is a contradiction but rather how severe the contradiction is. ${ }^{2}$ Similarly, Miller says that the position of someone excluded permanently from citizenship because of a failure to pass the test is "anomalous and unenviable" (emphasis added), but he does not say that it is "unjust." Why not? I'm not sure whether his choice of language in these cases reflects an actual substantive view that such cases are not unjust and that there is no contradiction or rather that he simply thinks that such details are not worth talking about.

One way to read Miller is to say that he is focusing on the bottom line question: What immigration policy should a contemporary liberal democratic state adopt when we balance all of the competing considerations? So, perhaps he does not want to spend time on theoretical issues that do not affect this bottom line question. (And perhaps there are readers now who are thinking, "Good for Miller. I wish Carens would adopt that approach in this paper.") If that is the case, there is only a difference, not a disagreement, between Miller and me because, as I have indicated, our bottom line views on what is to be done about citizenship tests are not very different, and I think it is perfectly acceptable for a theorist to limit an investigation in various ways, including by explicitly bracketing questions that the theorist regards as unimportant or simply does not want to address for some reason.

On the other hand, I also think it is perfectly appropriate for a political theorist to be interested in the question of what justice requires in principle, even when, or perhaps especially when, there is a difference between what the theorist thinks is right in principle and what the theorist thinks should be pursued as a matter of public policy. There are parts of Miller's discussion that seem to be open to this sort of reflection as well. In his discussion of how we should define refugees, for example, which I consider more fully below, Miller distinguishes between the definition we should adopt for legal and political reasons and the definition we should adopt for purposes of philosophical reflection. That seems to imply a theoretical approach that is open to the recognition of a wider gap between principle and policy than will be allowed by someone only interested in the bottom line. To put it another way, is Miller willing to distinguish between the

\footnotetext{
${ }^{2}$ I am assuming here that in ordinary usage the term "contradiction" admits of degrees, unlike the term "unique."
} 
CARENS Why Do Political Philosophers Disagree?

question "What does justice require in principle?" and the question "What is to be done here and now?"

If Miller is open to considering such questions, then it seems as though there may be a substantive disagreement between him and me after all, though I confess that I remain a bit puzzled about the nature of the disagreement. So far as I can tell, it is not a disagreement about any empirical claim (e.g., about the consequences of one policy rather than another). It might be a disagreement about the appropriate use of terms like justice or it might be a disagreement about the logical structure of the arguments or, finally, it might be a disagreement about the relative value to be placed on competing moral considerations. I confess that I am unclear about the nature of our differences on this topic.

\section{Obligations to refugees}

Turn now to questions about refugees. Once again, the first point to note is how much Miller and I agree at the level of general principles. First, he says that the definition of who counts as a refugee under international law is too narrow from a philosophical perspective. In principle, he argues, the category of refugee should be expanded to include "Those whose human rights are under threat [regardless of the source] ... and who can only avoid this threat by migrating." (82) At the same time, Miller thinks that it would be unwise to try to change the definition used in international law because the political dynamics of such an effort might lead to fewer refugees gaining protection. (82-83) I agree with both of these claims. I want to draw attention again to the fact that this view entails a recognition on Miller's part of the possibility of an important gap between what we think is right in principle and what policy we think we ought to pursue.

Second, Miller says that "refugees are people toward whom states have more stringent obligations than toward immigrants in general" and that this includes a "duty of care toward them that includes not sending them back to the place of danger they have escaped from, under the principle of non-refoulement." (78, italics in original) Again, I agree.

Third, Miller says that what is owed to refugees depends in part on whether their needs are short term or long term. In the short run, what they primarily need is physical safety and the satisfaction of their material needs, such as food, clothing, shelter, and healthcare, and these can (in theory) be supplied in a camp. In the long run, it is different:

As the time period extends, it becomes essential that the refugee should be in a place where he has opportunities for work and recreation, can have his children educated, can practice his religion - in other words, is able to engage in all of the activities that make up a decent human life. (86)

Again, I agree fully with this.

Fourth, Miller says that the general moral responsibility to provide for refugees "is shared among all those states who are able to help the refugee by admitting her." (83) Miller thinks, however, that sometimes a state can have a special responsibility to provide for a particular refugee or group of refugees. For example, states have a special responsibility for refugees whose plight is the result of something the state itself has done. (90) In addition, a refugee can create a specific 
CARENS Why Do Political Philosophers Disagree?

moral obligation on the part of a particular state to care for her if she arrives physically in the state and seeks asylum because that renders her vulnerable to that specific state's actions in a way that refugees elsewhere are not. (85) Letting the refugee's decision about where to apply for asylum determine who will be responsible for caring for the refugee is not a fair way of dividing up the general responsibility for refugees, however. Again, I agree with all of these claims, though I would add that I think the preferences of refugees with regard to where they will go deserve to be given moral weight, especially in cases of permanent resettlement, and so ought to be taken into account (but not necessarily be treated as decisive).

How should the general responsibility to admit refugees be divided among particular states? In his concluding chapter, Miller says, "each state needs to make a conscientious effort to work out what its fair share of the refugee burden should be and to admit on that basis." (162) He goes on to acknowledge that, for domestic political reasons, each state is likely to face "an incentive to underestimate what that share amounts to," and so he also posits "a duty to make a good faith attempt to set up an international mechanism to oversee refugee flows... and to precommit to complying with its recommendations, at least up to an agreed threshold on numbers." (162-163) Once again, I agree with Miller, and I find this a very attractive statement at the level of principle. Indeed, I would be extremely happy to see any movement in the direction of this idea. I have to add, however, that, as a policy proposal, this seems to me to be highly unrealistic from a political perspective, which, as we shall see, is something that Miller regards as an important objection to my argument for open borders. And so I do wonder what role, if any, realism is playing with respect to this particular part of Miller's discussion. I return to this below.

Finally, consider a point that Miller makes about the nature of our moral responsibility to refugees. Miller says, "the obligation to admit refugees ... is a remedial obligation in the sense that there would be no refugees in the first place unless other states were either actively violating or passively failing to protect the human rights of people living on their territory." (92) I agree with this statement.

So far, as you can see, there are many important areas of agreement between Miller and me on the topic of refugees. Now we have to consider differences, however. The key issue is what limits, if any, states may reasonably set on their willingness to provide for refugees without violating their moral responsibilities.

Miller asserts that because the obligation to admit refugees is a remedial obligation it is "limited by considerations of cost" and therefore each individual state may be justified in taking steps to ensure that its intake of refugees does not impose excessive costs on it. (92) He goes on to say,

The net effect...may be that there are some refugees for whom no state is willing to take responsibility: each receiving state sincerely and reasonably believes it has done enough, taking into account the cost of accepting refugees, to discharge its fair share of the burden. (93)

He describes this situation as "a tragic conflict of values." (93) In his concluding chapter, he elaborates upon the problem, after asserting that states have a duty to create an international 
CARENS Why Do Political Philosophers Disagree?

institution that can allocate responsibility for refugees fairly. ${ }^{3}$ First, he notes, even if we can imagine such an international institution, some states may simply refuse to take in the number of refugees they have been assigned (and Miller is not imagining that it will be possible for the institution to force them to do so). So then the question becomes whether the other states have a duty to "take up the slack" and admit additional refugees beyond their assigned fair share. The second question is "what should be done if the number of refugees we are asked to accept even under a fair distribution is greater than the number that can be accommodated and/or integrated without serious cost to social justice and cohesion." (163, italics in original)

Miller's answer to the first question, so far as I can tell, is that states that are doing their fair share in admitting refugees do not have an obligation, as a matter of justice, to take in additional refugees who have no place to go because other potential receiving states are failing to do what they should. And his answer to the second question is that justice does not require states to admit additional refugees when their admission would impose a "serious cost to social justice and cohesion" within the receiving society. Justice does require states to admit refugees up to this threshold when that is what a fair allocation entails, but beyond that threshold, the moral obligation to admit refugees is "humanitarian in nature." (163) Miller speaks of "obligation" here, but as I interpret his view, he is saying that admitting refugees beyond the serious cost threshold would be discretionary -- a supererogatory action, to use the categories of moral philosophy -- something morally admirable but not required.

This is where my views about our obligations to refugees diverge from those of Miller. Let me first briefly state my views and the reasons for them and then explore possible sources of the difference with Miller. First, in considering the two issues that Miller has raised ("taking up the slack" and "excessive costs"), we will benefit, I think, by keeping the two issues analytically distinct even though they may converge in the world. So, we should ask whether a state has an obligation to admit more than its fair share of refugees when doing so would entail real costs, but not ones that rise to Miller's serious cost threshold. And then it seems to me that the answer is clearly that there is an obligation to take up the slack and admit refugees because the failure to do so will leave the refugees deprived of their human rights and the cost to the receiving state of taking them in is, by stipulation, well short of any comparable burden, even though it is a real cost.

Keep in mind that, as Miller himself points out, our general obligation to admit refugees is a remedial obligation in the first place, i.e., it is an obligation to take up the slack created by the failure of the refugees' home states to do what justice requires, namely protect the human rights of their inhabitants. Miller himself (rightly) regards this general obligation to take in refugees as an obligation of justice, not merely a discretionary humanitarian obligation. So, why would taking in additional refugees when other states fail to do their part be any different? Of course, I understand why people in a society willing to take in its fair share of refugees would be mad at states that were not willing to do the same and why it might be politically difficult to persuade

\footnotetext{
${ }^{3}$ One of the reasons why such an institution is needed, Miller notes, is that states have strong incentives to underestimate their fair share. That seems to problematize the earlier idea that states may "sincerely and reasonably" believe that they have done enough.
} 
CARENS Why Do Political Philosophers Disagree?

people to take in additional refugees to make up for that failure. They might feel that taking in more would make them suckers, that their good will was being taken advantage of by the people in other states that could and should take in refugees but choose not to do so. But that does not change the facts (stipulated as such for purposes of analysis) that the refugees in question have basic human rights needs that can only be met by admission to another state, that no other state will admit them, and that our state can admit them without reaching the serious cost threshold. So, the rationale that created the obligation in the first place seems to apply in this one as well. Of course, one could argue about the incentive effects of advancing such a conception of obligation, but it is also possible to argue against the initial obligation to take in refugees on grounds of incentive effects, and people have done so. The actual incentive effects often vary according to circumstances and contexts. For example, the willingness of some states like Canada and Germany to take in Syrian refugees seems to have been increased rather than reduced by the unwillingness of others to do so.

Second, I am concerned with the way Miller identifies the serious cost threshold. I agree with Miller that there are limits to what justice can demand. Certainly, if the admission of more refugees would put the basic human rights of the receiving population in jeopardy, the state would be justified in refusing to take in more. But it seems to me that there is a great deal of space between that constraint and the one Miller wants to establish as a limit on the admission of refugees: "serious cost to social justice and cohesion." I think that Miller's standard gives too much weight to the interests of those in the receiving society when their interests conflict with the needs of refugees, even though the interests of those in the receiving society are important and even though states are normally entitled to give priority to the interests of their own population over the interests of outsiders.

When I took up the question of refugees in my own book, I began by talking about the way in which the legacy of the widespread failure to admit Jewish refugees in the 1930s should shape our thinking about this topic. I noted then that one of the objections to the admission of Jewish refugees was that there were too many potential refugees and that their admission would disrupt social cohesion and make it harder to provide for domestic populations that were still trying to recover from the Depression. I asserted that even if these concerns were well founded, they did not justify the exclusion of Jewish refugees, a claim that I posited as a shared starting point, a Rawlsian considered conviction of justice, in thinking about this topic. I suggested therefore that we should interrogate any proposed principle for dealing with refugees with the following question: What would this principle have entailed if it had been applied to Jews fleeing Hitler? And I contended that any principle that would have justified the decision by many states not to admit large numbers of Jewish refugees in the 1930s should be seen as morally problematic. Viewed from that perspective, it seems to me that Miller's serious social cost standard leaves too much space for restriction.

So, the question again is why do Miller and I differ on this issue of the limits of our obligations to refugees? One possibility is that we disagree about moral fundamentals regarding the extent and limit of our obligations to others or about the possibility of a deep conflict between justice and state self-interest, though that simply pushes the question back to the explanation of that 
CARENS Why Do Political Philosophers Disagree?

difference. I'll explore that possibility in the next sections. The possibility that I want to explore here is that we are really asking somewhat different questions, and that Miller is implicitly incorporating concerns about feasibility into his discussion of refugees to a greater extent than I am.

In my theoretical work on this topic, I have tried to explore the implications of what I take to be widely shared moral principles and understandings for our obligations to refugees. I acknowledge that what I think justice requires with respect to the admission of refugees is very far from what most democratic states are currently doing and that there is very little likelihood that any of them will come close to meeting their obligations (as I understand them) both because most people in these states do not share my view of what justice requires with respect to refugees and, more importantly, because what is required (on my account) is so much in conflict with the interests of states and their current populations, at least as most people understand their interests.

But my approach to refugees is not the only one that political theorists can reasonably take to this topic. In fact, my approach brackets a number of important questions. ${ }^{4}$ I take it to be a fundamental requirement of political ethics, for example, that when engaging in political action and making political choices, we should always take into account risks, probabilities, and consequences both of what we are recommending and of the likely alternatives. In actual politics, it is almost never enough to focus only on the intrinsic merit of a particular course of action, but, in a sense, that is exactly what I do in my book by focusing primarily on questions of principle. It would be entirely reasonable, in my view, for a theorist to take guiding practice as his or her primary aim and responsibility rather than exploring the implications of principle. A theorist who takes that sort of approach might frame her questions quite differently from mine. The key normative question might then be not 'what is right in principle?', but rather 'what is the best we can realistically hope for under this particular set of circumstances?' If one is interested in influencing public policy, it certainly makes sense to focus on the policies that are on the table (or at least on the side cupboard), not on ones that have no chance of adoption (regardless of why they are not feasible). And one may want to shape one's criticisms to foster the best possible outcome rather than to draw attention to the ways in which the best possible in a given context falls short of the best possible in principle. Focus on the latter may be demoralizing for those trying to work within the limits of the currently possible.

Let me give a concrete example of what a more practice oriented approach might entail when talking about refugees. If I were writing for the wider public about refugees, I would want to criticize the failures of Trump and May but I would also want to praise Merkel and Trudeau

\footnotetext{
${ }^{4}$ My approach also has certain practical dangers. One of the dangers is that if people were actually persuaded by my argument about the implications of moral principles, some of them might decide to drop the moral principles altogether rather than to support policies of admitting refugees that would be so contrary to their interests as they see them. One reason why I was willing to write my book anyway and state my views openly is that I think it is important for philosophers to seek the truth and tell the truth as best they can, but another is that I was quite confident that it was safe to do this in an academic book because very few people would read it anyway and those who did would be unlikely to be affected in this negative way.
} 
CARENS Why Do Political Philosophers Disagree?

because each of them has done a lot to expand the admission of refugees, especially as compared with other political leaders in liberal democratic states. From a principled perspective, one might well argue that even Germany and Canada are falling well short of their obligations to refugees, and one might object to particular decisions made by Merkel and Trudeau, but from the perspective of practical possibilities the important thing would be to encourage more Western states to follow their lead and also to support the idea that doing so could have positive political payoffs.

Does a concern for making practical recommendations to guide policy explain the differences between Miller and me on the topic of refugees? Well, not in any simple way. His most concrete discussion of policy matters regarding refugees comes not in the main text but in a postscript, and, even there, it is far from clear how "practical" his suggestions are. As I noted above, his suggestion that states should create a new international institution to allocate responsibility for refugees in a fair way is, to put it gently, unrealistic in the current context. Like me, Miller writes much more as a philosopher than as an engaged theorist worried about the actual calculations and tradeoffs that must be made if one seeks to guide policy. On the topic of refugees at least, he appears to me to be concerned primarily with questions of principle.

The difference between Miller and me on the topic of refugees is not about a practical question of what policies to support or about how to evaluate the current policies of liberal democratic states which Miller and I both agree fall well short of what justice requires. What we disagree about is only the question of how far short of justice current policies fall. And that is a debate about a philosophical principle which, as far as I can see, has no concrete implications for practical policies. Nevertheless, there is a concern for realism that runs through Miller's work, and it is at least possible that this realism is shaping his account of the limits of our obligations to refugees. I will explore this issue further in the next section.

\section{Methods: Realism and Idealism}

The biggest difference between Miller and me would appear to be that I think that justice requires open borders and he does not. I think that the difference is real, and that there is a disagreement behind that difference, but it is not so easy to understand where the difference lies and what the nature of the disagreement is. Miller himself seems to say at times that the crucial difference between us is that I am adopting a more idealistic approach to political theory, and he is adopting a more realistic one. Let's see if that is where the disagreement lies. In what sense is Miller taking a more realistic approach than I am, and does that affect our views of the open borders question?

Miller introduces these issues early on in his book in a passage that he explicitly constructs as a contrast between my approach and his own:

...what should we take as given and what should we regard as amenable to change when discussing immigration[?] How realistic or idealistic should we be?... 
CARENS Why Do Political Philosophers Disagree?

The argument for swallowing a considerable dose of realism here is that the immigration issue would either disappear altogether or at least become much less pressing in a world that was configured quite differently from our own....If we assume a fully just world, there would be no refugees, and no one seeking to escape desperate poverty. So all the factors that make immigration such a controversial issue for us would be absent in this hypothetical world. One could therefore "solve" the immigration question by prescribing that the world should become stateless or distributively just, but how much practical light would that throw on our predicament? (17, italics in original)

But Miller's realism does not imply that he thinks one cannot be critical of the status quo. In his conclusion, he notes that the position he has defended "rules out a fair amount of what most of the developed democracies would prefer to do and are actually doing in their treatment of immigrants." (164) I think that is an accurate description, and, for just that reason, I suspect that most policymakers would think that Miller had not swallowed a big enough dose of realism. From a practical perspective, he seems pretty idealistic.

What puzzles me is why Miller thinks that his approach conflicts with, or even contrasts sharply with, my own. In fact, I agree with every sentence in the cited passages (except the disparaging remark about solving the immigration problem with an account of a just world). In the methodological appendix to my book, I make exactly the same point that Miller does here, that many important immigration issues (such as the issues of refugees and irregular migrants), would largely disappear in a just world and that it is important to think about these issues. So, I argue, one should adopt an approach that does not make them disappear, i.e., a realistic approach that simply takes as given many of the features of the modern world.

At the same time, I caution that a realistic approach has its own dangers. It can "solve" the problem of global injustice by assuming it away. That does not shed theoretical light on our situation, in my view. On the contrary, it obscures the factors that give rise to the immigration problems that we face today, factors that deserve to be subjected to critical scrutiny.

The solution to this dilemma is to seize both of its horns. It makes sense, I suggest, to start with "a considerable dose of realism" in order to reflect upon immediate problems, but then it also makes sense to swallow a considerable dose of idealism (to use Miller's image) in order to get a different perspective, one that can illuminate some of the underlying issues of global justice. I think it is possible to have an intellectually coherent account that utilizes both approaches (and some in between) so long as one is conscious of and explicit about the perspective from which one is seeing and speaking in a given moment.

As I have said, I am sympathetic to Miller's realism, so long as that is not constructed as the only possible perspective, and that sympathy is reflected in the fact that we agree in many respects both on what questions we ought to ask about immigration in the world in which we live and on how we ought to answer those questions. The wide areas of agreement can be seen in my summary of our positions above. 
CARENS Why Do Political Philosophers Disagree?

It seems to me that Miller himself implicitly adopts an "idealistic" approach in parts of his book in the sense that he feels it necessary to talk about fundamental underlying moral principles, not just about policy choices within the constraints imposed by the existing order of things. Indeed, I think that Miller has a view of what global distributive justice requires and that he thinks that it does not entail the kind of equality that he presupposed (for purposes of argument) in the text. His footnote says as much. (178, n.35) So, Miller's opposition to my argument that a just world would have open borders does not rest only on his view that it is not helpful for present purposes to think about what a just world would require with respect to immigration. He also thinks that a just world would not require open borders and would permit states to exercise considerable control over immigration.

\section{Cosmopolitanism and Partiality}

What underlies Miller's opposition to the open borders argument, I think, is not really a commitment to a monolithically realist approach but a conception of what justice requires in some fundamental sense. That is why he spends chapter two of his book exploring the proper place of cosmopolitanism and partiality in our moral understanding of the world. In Miller's view justice requires respect for the particularistic claims of political communities, and he sees that as ultimately incompatible with a commitment to open borders because he sees the open borders argument as tied to a moral cosmopolitanism that has no space, or at least too little space, for particularistic moral claims. ${ }^{5}$

What puzzles me about Miller's view is why he thinks that a strong version of cosmopolitanism that leaves no space for particularistic moral claims is entailed by any defense of open borders, and, in particular, by mine. Miller is not entirely opposed to cosmopolitanism defined as a commitment to the idea that all human beings are of equal moral worth. He describes his own position as "weak cosmopolitanism," a view that sets serious limits to partiality, as we have seen, requiring states to respect the human rights of all subject to their jurisdiction and that entails further (limited) obligations to outsiders. So, why couldn't moderate cosmopolitanism be another option - something between Miller's own weak cosmopolitanism and the strong cosmopolitanism that he rejects. Indeed when Miller first mentions my book, he seems to recognize that this is precisely my position, though in fact I do not myself use the term cosmopolitan to describe it. Miller characterizes my account as "cosmopolitan" in the text but in a footnote he says,

Carens's version of cosmopolitanism is not extreme, inasmuch as it allows states to give some priority to the interests of their own citizens over those of foreigners. Nevertheless, Carens believes that basic liberal principles of free movement and equal opportunity must be applied on a global scale, which directly entails unimpeded migration across state borders. (178, n.33)

\footnotetext{
${ }^{5}$ Miller recognizes that some cosmopolitans try to create space for particularistic moral claims by appealing to the instrumental value, from a cosmopolitan perspective, of institutional arrangements that assign particular moral responsibilities on the basis of particular ties. (24-25)
} 
CARENS Why Do Political Philosophers Disagree?

As I have said so often in this paper, I agree entirely with these sentences of Miller. This is a perfectly fair two sentence summary of my position, even though, as I just noted, I do not use the term cosmopolitan to describe my own view. But subsequently this possibility of a moderate cosmopolitanism seems to drop from Miller's view.

In chapter two, we are told that we must choose between an implausible strong cosmopolitanism that "seems to rule out not only partiality toward one's compatriots, but any kind of special concern at all, such as concern for our families, friends, and colleagues" and Miller's own version of weak cosmopolitanism (23). My own version of a cosmopolitanism that is by Miller's own account "not extreme" and that does give some priority to the interests of compatriots seems to have disappeared from Miller's view. ${ }^{6}$ Indeed, Miller implicitly associates me with the strong version of cosmopolitanism:

$[\mathrm{M}]$ any political philosophers are critical of ...partiality towards compatriots... Such critics often describe themselves as cosmopolitans and appeal to cosmopolitan principles when mounting a case for open borders, as for example in the case of Joseph Carens.... (22)

Here, I have to say, I do not endorse Miller's sentences and I do not think his account is fair. I am critical of partiality towards compatriots in some respects, but so is Miller, and I am supportive of compatriot partiality in other respects, as Miller had previously noted. As I have said, I did not describe myself as a cosmopolitan in my book. I chose not to do so precisely because of the associations that the word has and the tendency that some people have to assume that all cosmopolitans are strong cosmopolitans. I was at pains in my book to make clear that most of the arguments I was advancing, especially in the first several chapters, were not cosmopolitan arguments and did not depend on cosmopolitan principles understood as appeals to the moral equality of all human beings. They are appeals to the moral claims that derive from membership in a society. In other words, they are particularistic claims, not universal claims. On the other hand, the argument for open borders can reasonably be described as "an appeal to cosmopolitan principles," but that is also true of Miller's arguments about refugees and of his claim that a state has a moral duty to respect the human rights of anyone subject to its jurisdiction.

One of the central goals of my book was to argue that contemporary democratic principles broadly understood entail that human beings have some legitimate moral claims that arise from universal principles, others that arise from particular connections, and others still that arise from a combination of both. Often these legitimate moral claims are complementary. The particularistic claims can co-exist with the universal ones. To make that point explicit, I return at the end of my book to the conclusions that I reached in the first part while assuming that states

\footnotetext{
${ }^{6}$ There are many other versions of moderate cosmopolitanism besides mine that also fall between Miller's weak cosmopolitanism and his account of strong cosmopolitanism and that also disappear from view in the dichotomy that he constructs. I do not discuss them because the focus in this paper is only on the differences between Miller and me.
} 
CARENS Why Do Political Philosophers Disagree?

were morally entitled to exercise great discretionary control over immigration, and I argue that many of the conclusions reached previously about access to citizenship, the treatment of temporary and permanent residents, and the integration of immigrants would still be valid in a world of relative equality between states and open borders. In my view, there is still considerable space for particularistic claims in a just world. Sometimes, however, these universal and particularistic moral claims conflict with one another, and then the challenge is to balance competing considerations fairly. I do not assume that moral claims based on universal principles should always trump moral claims based on particularistic ones.

As I read Miller, he has essentially the same view but he strikes the balance between the competing considerations a bit differently from me. I want to probe a bit further into the question of why Miller seems to regard the conflict between his views and mine as so much deeper than I do. I think that it is because Miller believes that a commitment to open borders is fundamentally incompatible with a serious and deep respect for the particularistic claims of political communities.

Just before the passage cited above from his first chapter, Miller describes my two stage approach, i.e., my first assuming that states are justified in controlling borders and then removing that assumption and making the case for open borders. He says that I have helpful things to say about the treatment of immigrants in the first stage but he worries about the tension between the two stages:

If one's underlying commitments are indeed cosmopolitan, then it will be difficult to take seriously the justifications that are usually given to support policies such as requiring immigrants to take citizenship tests or affirm their loyalty to the state they have joined. One can assess how onerous these requirements are, and judge their acceptability on that basis, but underneath one must find all such practices unjustified. Imagine someone who is fundamentally opposed to marriage being asked for advice on a friend's wedding arrangements. It will be hard to make suggestions that are not in some way colored by the thought that the whole enterprise is a mistake. At best the advice will amount to damage limitation. (16)

If I understand the passage correctly, Miller's suggestion is that someone like me who thinks that justice requires open borders won't really be able to suspend the underlying "cosmopolitan commitments" that lead to that view when thinking about other immigration related questions within the constraints of a conventional view about state control over immigration that I ultimately reject. So, Miller thinks, the cosmopolitan commitments that lead to my open borders view will influence and distort answers to questions about matters like access to citizenship or social integration.

Miller's passage is puzzling for both methodological and substantive reasons. At a methodological level, adopting an assumption that one does not fully accept in order to clarify analytical issues is a staple of the kind of philosophical work that Miller and I do. Miller uses the technique himself on the very next page in an effort to show the limitations of what one can learn from an idealistic account of global justice. He says, "Suppose that states remained the basic 
CARENS Why Do Political Philosophers Disagree?

sources of political authority, but the world was 'distributively just' insofar as conditions of life were more or less the same everywhere." (17) As he explains in a footnote, he puts 'distributively just' in scare quotes because he does not himself believe that global distributive justice requires that sort of equality. So, he assumes here ("suppose that") a normative idea that he does not himself accept in order to say something about what does and does not follow from that idea. That is precisely what I do for much of my book in assuming that states are morally entitled to exercise considerable discretionary control over immigration.

It is perhaps not unreasonable to suspect that when people adopt an assumption merely for the sake of the argument and not because they actually accept it that their exploration of the implications of that assumption may be distorted in some way, but suspicion is not proof. The challenge for the critic is to show precisely where the flaw in the argument appears and why it is a flaw. It cannot be enough to suspect that a commitment to open borders will distort one's views on other issues even when the discussion is framed without that commitment. The challenge for Miller is to show how that underlying commitment has distorted my analysis.

This leads to the substantive reason for my puzzlement. As should now be clear from the earlier discussion in the paper, the striking fact is that Miller and I agree upon a great deal with respect to questions about how states ought to treat immigrants and even with respect to questions about admissions, within the constraints of the conventional view that states have considerable discretion in dealing with immigration. We not only reach the same conclusions but we offer the same rationales for these conclusions in most cases. If my underlying open borders commitment were distorting my arguments about these other questions, one might expect those distortions to have more of an impact on the conclusions and the reasoning that supports them. Of course, it is possible that the distortions show up precisely at the points where I do disagree with Miller (e.g., regarding the nature of citizenship tests or the limits on national identity), but that is a claim that again would require a supporting argument.

At a deeper level, the puzzle about the quoted passage is that it presupposes that a commitment to open borders implies a fundamental antagonism to the particularistic claims of political communities. The passage is not idiosyncratic in that respect. That presupposition governs the whole structure of Miller's discussion of cosmopolitanism and compatriot partiality in chapter two of his book.

To see what is problematic about presupposing a fundamental conflict between open borders and the claims of particular communities, it may be helpful to pause for a moment to reflect upon Miller's analogy with seeking advice on wedding arrangements from someone opposed to marriage and his skepticism that such advice could be truly helpful. Why might a person be fundamentally opposed to marriage and why might someone getting married ask such a person for advice about wedding arrangements? There are different sorts of reasons for opposition to marriage. If a person is really opposed to marriage in principle not only as it exists today but under any imaginable circumstances, then it is probably true that the advice one would get would have the character that Miller describes - damage limitation - and it is hard to see why someone who has decided to get married would ask such a person for advice in the first place. 
CARENS Why Do Political Philosophers Disagree?

Suppose instead that the person is not opposed to marriage as such, understood generically as an institution in which people can make ongoing deep life commitments to one another in a public way, but is opposed to marriage as it has existed traditionally, that is to say, an institution in which mutual, life-long commitment is intertwined with and shaped by patriarchal and heteronormative values, an institution that has excluded some people altogether (e.g., those in same-sex relationships) and that has entailed the subordination of the wife to her husband. Then one can imagine someone about to get married asking a friend with such views for advice about wedding arrangements. The people getting married might say, "Look, we really do believe in making a public commitment to one another to live our lives together but we don't want to reproduce the problematic features of traditional marriage in our wedding arrangements. We know that you are attuned to these concerns. Can you help us think through what wedding arrangements would be appropriate for people with our values and commitments?"

Even in a world in which same-sex marriage is legal and most wives do not promise to obey their husbands, we might find upon reflection that there is quite a bit of patriarchy and heteronormativity left in the wedding arrangements for most marriages as well as in the functioning of the institution itself in ordinary life. So, a person critical of that patriarchy and heteronormativity and sensitive to their pervasive influence might indeed be able to offer some constructive advice about what elements in the usual wedding arrangements are worth keeping and what ones implicitly embody problematic values. That advice could be described as "damage limitation," but, in my view, it would be more positive and constructive than that.

In fact, I would guess that lots of people today (both straight and gay) have actually struggled with this sort of question. Marriage seems like an attractive ideal in the abstract but it has a sorry history. Are there any parts of the institution (not only the formal rules but also the informal expectations) that we can keep without buying into marriage's dark side? Lots of people think that the correct answer to that question is 'no,' but I confess that I remain optimistic about the possibility of a form of marriage as an institution that is valuable and worthwhile, even if not one that everybody will want to embrace.

I have sort of the same attitude toward the nation state, both personally and intellectually. My project is precisely to see what, if anything, can be salvaged from the sorry history of the nationstate, what features of belonging to a political community can be respected and even celebrated by people with democratic and egalitarian commitments. Even though I think that justice requires open borders, I am not an anarchist. (Not that there is anything wrong with that, as Seinfeld used to say.) I am also not a cosmopolitan who rejects partiality in all its forms.

At a personal level, I feel quite attached to Canada, the country to which I moved as an immigrant over 3 decades ago. I identify with the community and care more about how it fares in the world than I do about most other states. I also feel attached to the United States, Donald Trump notwithstanding, because it is the place where I was born and raised and spent much of my life as a young man, where all of my family of origin still lives, and where I am still a citizen (as well as being a citizen of Canada). So, I care particularly about the fate of America as well. (Sad!) 
CARENS Why Do Political Philosophers Disagree?

At an intellectual level, I feel the attraction of a social order in which most people see themselves as members of a particular political community with which they identify and which they want to help to direct. As with the institution of marriage, however, I'd like to see the institution of the nation state exist in a way that does not entail all of the negative features that have been so much a part of its history, and, in particular, the exclusion and domination of outsiders.

Just as there are critics who see marriage as an outmoded and fatally flawed institution, there are critics who see the nation-state the same way. They think it is naïve to imagine that one could ever have the nation-state as an institution without these dark dimensions. Like Miller, these critics think that I am not being realistic enough, although from their perspective, the failure of my realism is not my unwillingness to accept the inequalities and constraints that characterize the nation-state today in its dealings with those outside its borders but my unwillingness to recognize the impossibility of the institution ever transcending these limitations. So, when you map the alternatives in this way, my position is really the moderate one, a mean between two "realistic" extremes.

\section{Conclusion}

There are many other topics small (e.g., the use of examples in political theory, the distinction between an ethical and a political theoretical approach to immigration) and large (the nature of a just world, the interests served by open and closed borders) on which Miller and I appear to differ, and some on which I think we genuinely disagree. But this is already a very long paper. I hope to have shown that sometimes it can be just as fruitful to focus on areas of agreement and on ways to narrow intellectual differences as it is to concentrate on disagreements. 